\title{
Effect of Planting System and Partial Removal of the Epidermis of Cassava Cuttings on Growth Yields and Root Development ${ }^{1}$
}

\author{
J. Badillo-Feliciano and M. A. Lugo-López ${ }^{2}$
}

\begin{abstract}
A field experiment was conducted on a Coto clay, an Oxisol, to compare the effect of planting cassava cuttings vertically with a section above ground or horizontally underground and of removing the epidermis (ringing) of the cuttings at either the basal or terminal end, or at the middle, and some combinations of these treatments. The experiment followed a randomized complete block layout with eight treatments and four replications. Data obtained from an 8-month-old cassava crop reveal no significant differences in edible root yields when planted either vertically with a section above ground or horizontally underground. Removing rings of the epidermis did not affect yields significantly. Mean height of plants from cuttings planted vertically without rings was significantly higher than that of plants from cuttings set horizontally with rings at both ends. No significant differences in top-to-root ratios were attributable to treatment. Counts and observations of cuttings grown on sand beds under greenhouse conditions indicate that, contrary to the generally accepted belief, roots are produced more abundantly from calluses formed at the basal area where the incision is made at cutting than at nodes below ground level. Irrespective of treatments, overall yields were more than twice those obtained in subsistence and commercial farming. This can be attributed to the use of a high yielding cultivar and sound soil and crop management practices.
\end{abstract}

\section{INTRODUCTION}

Cassava (Manihot esculenta, Crantz), the subsistence crop produced in largest quantities in tropical America, has received relatively little attention from researchers. Thus, literature on the subject is rather scanty. The concept that the crop is suited to rather low fertility soils and that, except for good drainage, it does not appear to be very demanding as to soil and crop management conditions has probably contributed to this situation. However, cassava is very valuable as an energy source,

${ }^{1}$ Submitted to Editorial Board December 17, 1975.

${ }^{2}$ Associate Agronomist, and Professor and Soil Scientist, respectively, Agricultural Experiment Station, Mayagüez Campus, University of Puerto Rico, Río Piedras, P.R. 
producing $493 \mathrm{kcals} / \mathrm{lb}^{3}$. Edible roots, on an average, contain about $33 \%$ carbohydrates but only about $1 \%$ protein and $0.3 \%$ fat ${ }^{4}$. They are relatively high in $\mathrm{Ca}, \mathrm{P}$, and $\mathrm{Fe}$. The crop is also relatively drought resistant. Propagation is generally by cuttings obtained from the stems of mature plants. They are planted either vertically with a section above ground or horizontally underground. The main objective of this work was to evaluate both planting systems. The cuttings produce roots both from the nodes below ground and from the calluses developed at the internodes at the area where the incision is made at cutting. The observation that root formation seems to be induced by small incisions on the epidermis ${ }^{5}$ further led to the study of the possible effects of ringing (partial removal of the epidermis) on root development, plant growth, and crop yield.

\section{MATERIALS AND METHODS}

The experiment was conducted on a Coto clay, a Tropectic Haplorthox, clayey, kaolinitic, isohyperthermic, at the Isabela Substation farm. The soil at the experimental site had a $\mathrm{pH}$ of 5.0 ; the organic matter content was $4.2 \%$, and the CEC, $13.3 \mathrm{meq} / 100 \mathrm{~g}$ of soil.

The experiment followed a randomized complete block design with eight treatments and four replications.

Treatments were planted as follows: 1) Vertically with no rings; 2) vertically with one ring at basal end; 3) horizontally with no rings; 4) horizontally with one ring at basal end; 5) horizontally with rings at each end; 6) horizontally with rings at each end and at the middle; 7) horizontally with one ring at the middle; and 8) horizontally with one ring at the basal end and one at the middle.

Each plot consisted of a row $3.4 \mathrm{~m}$ long with 7 plants/plot. Rows were spaced $0.9 \mathrm{~m}$ apart. MC-22, a high yielding cassava cultivar introduced from Colombia, South America, was planted on January 28, 1975, and harvested 8 months later. Individual plants received $57 \mathrm{~g}$ of a 10-10-10 fertilizer at planting time and again 2 months later. Irrigation was applied as necessary to supplement rainfall. The cassava plants were free of disease and insect pests throughout the growing season; thus, no control measures were necessary.

The following measurements were made and the data were subjected to analyses of variance: Marketable weight and number of roots,

${ }^{3}$ Gurney, J. M., Nutritional considerations regarding staples, Paper presented at the 12th Annual Meeting, Caribbean Food Crops Society, Kingston, Jamaica, July 1974.

${ }^{4}$ Litzenberger, S. C. (Ed), Guide for field crops in the tropics and subtropics, Agency for International Development, Washington, D.C. p. 231, 1974.

${ }^{5}$ Montaldo, A., Cultivo de raíces y tubérculos tropicales, Inst. Int. Cienc. Agr., OEA, Lima, Perú, p. 73, 1972. 
nonmarketable weight and number of roots, plant weight, plant height, plant diameter $5 \mathrm{~cm}$ from the soil surface, top-root ratio, and average root length of 10 roots. Observations were made on root distribution under field conditions.

Cassava cuttings with treatments similar to those included in the field test were planted on a sand bed in the greenhouse, and root counts and other observations were made on root development.

\section{RESULTS AND DISCUSSION}

Data on the effect of planting systems on yield, plant height, plant diameter, plants/set, top-to-root ratio, and average root length are given in table 1. An overall examination of the data shows that there were no significant differences in yields of edible roots when stem cuttings were planted either vertically with a section above ground or horizontally underground. Plants from cuttings set vertically with basal rings or without rings, yielded significantly higher than those planted under ground with rings both in the middle and at the basal end. There were no other significant differences in yields between plants from cuttings either with or without rings planted vertically above ground or horizontally underground.

In general, a field wide average of over $34 \mathrm{t} / \mathrm{ha}$ of marketable edible roots was obtained, a good yield for an 8-month crop, much better than those obtained on subsistence and commercial fields, which are usually around 10 to $12 \mathrm{t} / \mathrm{h}$ a for 12 -month crops. This can be attributed to the use of sound soil and crop management practices, including the use of a high yielding cultivar, planting at the right time, high plant population density, supplemental irrigation, and rational use of fertilizers. Data on total yield (marketable and culls) followed a trend similar to that on marketable yield. Nonmarketable edible roots ranged from 2.6 to $3.6 \mathrm{t} / \mathrm{ha}$ in all treatments.

Plant height fluctuated from $179.9 \mathrm{~cm}$ for the vertically planted ringless cuttings to $154.8 \mathrm{~cm}$ for the horizontally planted underground cuttings with rings at the two ends. These differences were significant.

Plant diameter ranged from $2.89 \mathrm{~cm}$ for the vertical ringed cuttings to $2.39 \mathrm{~cm}$ for the horizontal underground cuttings with rings in the middle and at the basal end.

The highest number of plants per set was obtained in the cuttings planted horizontally underground with rings in the middle and at each end. In contrast, the vertically planted cuttings tended to develop fewer plants per set. Usually, two plants emerged from cuttings that were ringed at the middle and they behaved like individual plants. The low yield of each single plant may be explained on the basis of the 
TABLE 1.-Effect of planting system and cutting preparation on cassava yields and plant characters

\begin{tabular}{|c|c|c|c|c|c|c|c|}
\hline \multirow{2}{*}{$\begin{array}{l}\text { Planting system and } \\
\text { preparation of cuttings }\end{array}$} & \multicolumn{2}{|c|}{ Yield } & \multirow{2}{*}{$\begin{array}{l}\text { Plant } \\
\text { height }\end{array}$} & \multirow{2}{*}{$\begin{array}{l}\text { Plant } \\
\text { diameter }\end{array}$} & \multirow{2}{*}{ Plant/set } & \multirow{2}{*}{$\begin{array}{l}\text { Top/root } \\
\text { ratio }\end{array}$} & \multirow{2}{*}{$\begin{array}{l}\text { Mean length } \\
\text { of root }\end{array}$} \\
\hline & Marketable & Total & & & & & \\
\hline & \multicolumn{2}{|c|}{ Metric tons/ha } & $\mathrm{Cm}$ & $\mathrm{Cm}$ & No. & & $\mathrm{Cm}$ \\
\hline \multicolumn{8}{|l|}{ Vertically } \\
\hline No rings & $36.4 \mathrm{ac}^{1}$ & $40.0 \mathrm{ac}$ & 179.9 a & $2.74 \mathrm{ab}$ & $1.4 \mathrm{bd}$ & $1.36 \mathrm{a}$ & $24.1 \mathrm{a}$ \\
\hline Basal ring & $39.7 \mathrm{a}$ & $43.3 \mathrm{a}$ & $162.7 \mathrm{ab}$ & $2.89 \mathrm{~b}$ & $1.3 \mathrm{bd}$ & $1.26 \mathrm{a}$ & $27.0 \mathrm{a}$ \\
\hline \multicolumn{8}{|l|}{ Horizontally } \\
\hline No rings & $33.8 \mathrm{abc}$ & $37.0 \mathrm{abc}$ & $178.5 \mathrm{a}$ & $2.76 \mathrm{ab}$ & $1.4 \mathrm{bd}$ & $1.35 \mathrm{a}$ & $27.2 \mathrm{a}$ \\
\hline Basal ring & $29.8 \mathrm{abc}$ & $32.9 \mathrm{abc}$ & $178.7 \mathrm{a}$ & $2.72 \mathrm{ab}$ & $1.5 \mathrm{bc}$ & $1.53 \mathrm{a}$ & $28.7 \mathrm{a}$ \\
\hline Rings at each end & $27.9 \mathrm{bc}$ & $30.5 \mathrm{bc}$ & $154.8 \mathrm{~b}$ & $2.60 \mathrm{ab}$ & $1.2 \mathrm{bd}$ & $1.59 \mathrm{a}$ & $26.4 \mathrm{a}$ \\
\hline Rings at each end and at the middle & $31.0 \mathrm{abc}$ & $33.9 \mathrm{abc}$ & $167.7 \mathrm{ab}$ & $2.54 \mathrm{ab}$ & $1.9 \mathrm{ac}$ & $1.31 \mathrm{a}$ & $25.2 \mathrm{a}$ \\
\hline Ring at the middle & $34.7 \mathrm{abc}$ & $38.0 \mathrm{abc}$ & $177.8 \mathrm{a}$ & $2.54 \mathrm{ab}$ & $2.0 \mathrm{a}$ & $1.35 \mathrm{a}$ & 25.9 a \\
\hline Basal ring and ring at the middle & $24.0 \mathrm{~b}$ & $26.9 \mathrm{~b}$ & $166.4 \mathrm{ab}$ & $2.38 \mathrm{a}$ & $1.8 \mathrm{acd}$ & $1.41 \mathrm{a}$ & $26.1 \mathrm{a}$ \\
\hline
\end{tabular}

${ }^{1}$ Means with letters in common are not significantly different at the $5 \%$ level of probability. 
TABLE 2.-Number of roots of cassava cuttings planted on sand beds under various treatments

\begin{tabular}{|c|c|c|c|c|c|c|c|c|c|c|}
\hline \multirow{3}{*}{$\begin{array}{l}\text { Planting system and } \\
\text { preparation of cuttings }\end{array}$} & \multicolumn{10}{|c|}{ Number of roots at indicated section of cutting } \\
\hline & \multirow{2}{*}{$\begin{array}{l}\text { Basal } \\
\text { incision }\end{array}$} & \multicolumn{3}{|c|}{ Rings } & \multicolumn{6}{|c|}{ Nodes' } \\
\hline & & Basal & Middle & Terminal & 1 & 2 & 3 & 4 & 5 & 6 \\
\hline \multicolumn{11}{|l|}{ Vertically } \\
\hline No ring & 42 & - & - & - & 2 & 2 & 1 & 2 & 1 & 1 \\
\hline Basal ring & 0 & 34 & - & - & 1 & 2 & 1 & 1 & 0 & 1 \\
\hline \multicolumn{11}{|l|}{ Horizontally } \\
\hline No ring & 68 & - & - & - & 1 & 1 & 2 & 1 & 1 & 1 \\
\hline Basal ring & 0 & 33 & - & - & 1 & 2 & 0 & 1 & 1 & 2 \\
\hline Rings at each end & 0 & 13 & - & 0 & 2 & 2 & 0 & 0 & 0 & 0 \\
\hline $\begin{array}{l}\text { Rings at each end and at the } \\
\text { middle }\end{array}$ & 0 & 11 & 17 & 0 & 2 & 0 & $\mathrm{t}$ & 0 & 0 & 0 \\
\hline Ring at the middle & 15 & - & 9 & - & 2 & 1 & 2 & 0 & 0 & 0 \\
\hline Basal ring and at the middle & 0 & 20 & 8 & - & 2 & 0 & 0 & 0 & 0 & 0 \\
\hline
\end{tabular}

${ }^{1}$ Nodes below ground numbered successively from basal to terminal end. Node 1 is the closest to the basal end.

competition for space, nutrients, and available moisture between these plants within a limited volume of soil.

No significant mean differences in top-to-root ratio were attributable to treatment. Lower values indicate a tendency to produce more roots at the expense of foliage.

The root systems were well-branched. Under field conditions no specific root distribution pattern was attributable to ringing. Profuse rooting was always observed at the basal end of the cuttings. Length of edible roots was not affected by ringing; as an average, roots measured $26.32 \mathrm{~cm}$, which gives an indication of the short roots produced by variety MC 22 which appears to be suitable for mechanization. The roots of some cultivars often reach $40 \mathrm{~cm}$ in length, which hinders the possibility of mechanized harvesting.

Table 2 gives data on number of roots developed on cassava cuttings grown on sand beds under identical treatments as those grown under field conditions. Most of the roots developed from the basal incision or from the basal ring. Rings at the middle of the cuttings produced a sizeable proportion of roots.

According to Litzenberger6: "The cuttings produce roots from the nodes below ground level after planting..." However, the data and observations made at Isabela (table 2) indicate that roots are produced more abundantly from calluses formed at the point where the incision is made

${ }^{6}$ Litzenberger, S. C. (Ed), Guide for field crops in the tropics and subtropics, Agency for Int. Develop., Washington, D.C., p. 233, 1974. 
when preparing the cutting for planting. A very small proportion of roots are actually produced from the nodes below ground.

\section{RESUMEN}

Se realizó un experimento de campo en un suelo Coto arcilloso, un Oxisol, para comparar el efecto de la siembra de esquejes de yuca (cangres) vertical y horizontalmente y de remover la epidermis (anillar) en los extremos o en el medio del cangre y combinaciones de estos métodos. Se utilizó un diseño de bloques al azar con 8 tratamientos y 4 repeticiones. Los datos no revelaron diferencias significativas en rendimientos de raíces comestibles que puedan atribuirse al hecho de sembrar el cangre verticalmente con una sección fuera del suelo o de enterrarlo horizontalmente. La remoción de anillas de la epidermis no afectó los rendimientos significativamente. La altura media de las plantas procedentes de cangres sembrados verticalmente, sin anillas, fue significativamente mayor que la de plantas procedentes de cangres sembrados horizontalmente bajo tierra con anillas en ambos extremos. No se registraron diferencias significativas en la proporción de tallos y raíces que puedan atribuirse a los tratamientos. Observaciones hechas en cangres sembrados en arena, en un invernadero, revelaron que, contrario a la creencia prevaleciente, las raíces se desarrollan más abundantemente de los callos que se forman en los puntos de incisión que en los nudos bajo tierra.

Independientemente de los tratamientos, se obtuvieron rendimientos que sobrepasan el doble de los que se obtienen en pequeños huertos o en siembras comerciales. Esto puede atribuirse al uso de un cultivar de alto potencial productivo y a practicas de cultivo mejoradas. 